\author{
Indonesian Journal of Human Nutrition \\ P-ISSN 2442-6636 \\ E-ISSN 2355-3987 \\ www.ijhn.ub.ac.id \\ Artikel Hasil Penelitian
}

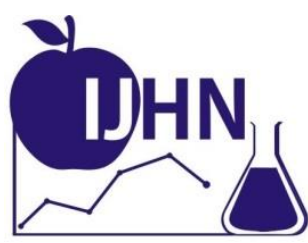

\title{
Kadar NF- Kß Pankreas Tikus Model Type 2 Diabetes Mellitus dengan Pemberian Tepung Susu Sapi
}

\section{(Level of Rat's NF-Kß Pancreas of Type 2 Diabetes Mellitus When Given Cow Milk Powder)}

\author{
Fajar Ari Nugroho ${ }^{1 *}$, Riska Mayang Saputri Ginting ${ }^{1}$, Nurdiana ${ }^{2}$ \\ 1 Program Studi Ilmu Gizi Fakultas Kedokteran Universitas Brawijaya \\ 2 Laboratorium Farmakologi Fakultas Kedokteran Universitas Brawijaya \\ * Alamat korespondensi, Email: fanmerah@gmail.com
}

Diterima: / Direview: / Dimuat: April 2015/ Agustus 2015/ Desember 2015

\begin{abstract}
Abstrak
Type 2 Diabetes Mellitus dihubungkan dengan kerusakan sel pankreas yang mempengaruhi jumlah dan fungsi insulin penderitanya. NF-K $\beta$ merupakan golongan protein dalam faktor transkripsi yang diduga memiliki peran penting dalam pro-apoptosis sel pankreas. NF-K $\beta$ merupakan pemicu pro- dan anti-apotosis sel beta pankreas dengan kecenderungan proapoptosis lebih besar dibandingkan peran anti-apoptosisnya. Vitamin D dari susu sapi bubuk adalah vitamin dengan kemampuan menghambat aktifitas NF-K $\beta$, melalui proses perbaikan sensitivitas dan produksi insulin, serta peningkatan pertahanan sel pankreas. Penelitian ini bertujuan untuk mengukur kekuatan efek pemberian susu sapi bubuk terhadap penurunan NFK $\beta$ pankreas tikus model type 2 diabetes. Selama 90 hari penelitian, tikus dibagi menjadi 5 kelompok, terdiri dari 2 kelompok kontrol (negative $=$ non-diabetic rat dan positive $=$ diabetic rat) dan 3 kelompok perlakuan (P1, P2 dan P3) dengan dosis pemberian tepung susu sapi adalah $0,9 \mathrm{~g} / \mathrm{hr}, 1,8 \mathrm{~g} / \mathrm{hr}$ dan $2,7 \mathrm{~g} / \mathrm{hr}$. Pada akhir penelitian kadar NF-K $\beta$ pankreas tikus diukur menggunakan metode Elisa. Hasil uji Mann Whitney U terhadap kadar NF-K $\beta$ kelompok perlakuan dibandingkan kontrol positif menunjukkan tidak ditemukan perbedaan ( $\mathrm{p}$ value $=$ 1,$000 ; 0,086 ; 0,248$ ). Efek penurunan kadar NF-K $\beta$ yang diharapkan dari pemberian susu sapi bubuk pada keadaan diabetes tidak terbukti. Sehingga disimpulkan pemberian susu sapi bubuk tidak dapat digunakan untuk mencegah kerusakan sel pankreas melalui mekanisme penurunan NF-K $\beta$.
\end{abstract}

Kata Kunci: Type 2 Diabetes Mellitus, NF-K $\beta$, vitamin D, susu sapi bubuk

\begin{abstract}
Type 2 Diabetes mellitus starts with the damage of pancreas cells and the loss of insulin sensitivity. Furthermore, it will lead to continuously progressive damage of pancreatic cells and
\end{abstract}




\begin{abstract}
worsening loss of insulin sensitivity. NF-K $\beta$ is discovered as protein transcription marker that is assumed to have a vital role in pancreatic cell apoptosis. NF-K $\beta$ has two different functions in apoptosis process. However, despite its anti-apoptosis function that it could protect the pancreas damage, NF-K $\beta$ tends to lead pancreas's cells death. On the other hand, vitamin D from cow's milk powder is known as a substance that can inhibit NF-K $\beta$ activity by improving insulin sensitivity, and it can rise the protection of pancreatic cells from death. This research aims to know the effect of cow's milk powder vitamin D to NF-K $\beta$ rate on type 2 diabetes rat models. For 90 days, the rats were divided into 5 groups of experiment, two groups of control, (negative $=$ non diabetic non treatment rats and positive $=$ diabetic non treatment rats) and three groups of treatment that they were administrated cow's milk powder with different doses $(0,9 \mathrm{~g} / \mathrm{day}, 1,8$ $\mathrm{g} /$ day and 2,7 g/day). At the end, all groups were measured to know the rate of NF-K $\beta$ by Elisa method. The final result showed that there was no difference of NF-K $\beta$ rates between positive control and treatment groups ( $\mathrm{p}$ value $=1,000 ; 0,086 ; 0,248$ ). The reduction NF-K $\beta$ effect expected from cow's milk powder administration was not proven. The conclusion was that cow's milk powder could not be used to protect pancreatic damage by the mechanism of lowering NF-K $\beta$ rates.
\end{abstract}

Keywords: type 2 diabetes mellitus, NF-K $\beta$, vitamin D, cow's milk powder

\section{PENDAHULUAN}

Type 2 Diabetes Mellitus merupakan salah satu masalah kesehatan dunia. Prevalensi diabetes diperkirakan akan terus meningkat dari $4 \%$ di tahun 1995 menjadi 5,4\% pada tahun 2025 [1]. Indonesia sebagai salah satu negara di dunia yang memiliki penderita diabetes terbesar ke-4 di dunia, diperkirakan akan ditemukan 21,3 juta jiwa penderita diabetes di Indonesia pada tahun 2030 [2].

Sindrom diabetes yang ditandai dengan berkurangnya jumlah insulin atau menurunnya sensitivitas insulin atau kombinasi keduanya [3]. Gangguan hormonal ini dilain sisi mendorong terjadinya pembentukan lemak. Penumpukan lemak secara berkelanjutan atau dikenal sebagai hyperlipidemia akan mengaktivasi system inflamasi. System inflamasi ini diaktifkan oleh NF-K $\beta$ melalui regulasi cyclooxygenase, lipooxygenase, cytokine, chemokine dan proses adesi molekul [4]. Pada keadaan diabetes, kegiatan NF-K $\beta$ akan memicu disfungsi sel beta pancreas sehingga terjadi apoptosis yang progresif pada sel tersebut [5].

Beberapa zat gizi diketahui memiliki aktifitas penghambatan pada kinerja NF-K $\beta$. Vitamin D adalah salah satu zat gizi tersebut. Peningkatan jumlah produksi insulin, perbaikan sensitivitas insulin dan peningkatan resistensi sel prankreas terhadap proses apoptosis adalah bagian dari kegiatan vitamin D [6].

Kemampuan vitamin D dalam memperbaiki produksi dan sensitivitas insulin dilakukan bekerjasama dengan kalsium. Calcium flux yang terganggu akan mengakibatkan terganggunya sekresi yang dilakukan oleh sel beta [3]. Melalui peningkatan ekspresi protein Calbindin-D28K pada site Vitamin D Response Element (VDRE) di sel beta, akan terjadi perbaikan regulasi kalsium pada sel. Proses ini akan mendorong penurunan sitokin inflamasi sehingga apoptosis menurun. Dilain pihak, vitamin D secara langsung bekerja pada perbaikan ekspresi gen reseptor insulin sel beta, hasil akhir yang diperoleh adalah peningkatan jumlah insulin yang dihasilkan dan perbaikan sensitivitasnya [7].

Manfaat vitamin D dapat diperoleh dari susu sapi termasuk salah satunya adalah produk dalam bentuk tepung susu. Konsumsi susu sapi di Indonesia dibandingkan dengan negara-negara ASEAN [8], dibuktikan dengan konsumsi susu sapi sebesar 11 $\mathrm{kg} / \mathrm{kapita} /$ tahun sedangkan konsumsi susu dunia sebesar $103 \mathrm{~kg} / \mathrm{kapita} / \mathrm{tahun}$ [9].

Berdasarkan uraian tersebut, ditemukan adanya kepentingan untuk menganalisis kemampuan tepung susu sapi dalam menurunkan kadar Nuclear Factor Kappa Beta $(\mathrm{NF}-\kappa \beta)$ pada tikus type 2 Diabetes Mellitus.

\section{METODE PENELITIAN}

Penelitian ini adalah penelitian in vivo dengan desain penelitian randomised posttest only control design. Tikus jantan Rattus Novergicus Strain Wistar digunakan dalam penelitian ini berjumlah 30 ekor 
berusia \pm 2 bulan dan memiliki rata-rata berat badan 180-250 g secara acak dibagi menjadi 5 kelompok.

Kelompok pertama adalah kontrol negatif (K-), tikus dengan diet normal dan non diabetes. Kelompok kedua adalah kontrol positif $(\mathrm{K}+)$, tikus dengan diet tinggi lemak dan induksi streptozotocin (diabetes). Sedangkan tiga kelompok perlakuan adalah tikus dengan diet tinggi lemak dan induksi streptozotocin (diabetes) yang diberi tepung susu sapi masingmasing: 2,25\% (P1), 4,5\% (P2) dan 6,75\% dari total pakan. Pemberian diet tinggi lemak dan diikuti dengan penyuntikan (induksi) STZ dilakukan untuk meniru kondisi Type 2 DM. Seluruh rangkaian penelitian dilakukan selama 91 hari berdasarkan ketetapan peneliti.

Diet normal adalah pakan dengan komposisi mix PARS (53\%), tepung terigu $(23,5 \%)$, dan air $(23,5 \%)$. Sedangkan diet tinggi lemak merupkan mix pakan dengan komposisi PARS (50\%), tepung terigu (25\%), lemak kambing (10\%), minyak babi $(8,9 \%)$, kuning telur $(5 \%)$, minyak kelapa $(1 \%)$, dan asam kolat $(0,1 \%)$. Tepung susu sapi diberikan mix dalam pakan sesuai dosis tiap kelompok perlakuan.

Penetapan jumlah rata-rata pemberian pakan perhari didasarkan pada pengambilan batas margin atas rata-rata karena perbedaan asupan individu tikus. Rata-rata asupan tikus perhari dalam beberapa referensi adalah 12-20 g/hari/ekor; 15-20 g/hari/ekor; 20-30 g/hari/ekor [10, 11]. Untuk mencegah terjadinya kekurangan pakan akibat berbedaan asupan individu dan adanya keadaan poliphagi pada saat hiperglikemia maka ditetapkan pemberian pakan adalah $40 \mathrm{~g}$ /hari/ekor.

Kandungan zat gizi dan energi pada pakan harian adalah $\pm 160 \mathrm{kal}$ energi, $28 \mathrm{~g}$ karbohidrat, $6 \mathrm{~g}$ protein, $2.5 \mathrm{~g}$ lemak, $400 \mathrm{IU}$ vitamin D dan $500 \mathrm{mg}$ kalsium. Pakan ini adalah pakan isokaloric dimana kandungan zat gizi berada pada kisaran yang sama walupun komposisi berbeda sesuai kelompok dan tahap perlakuan.

Diet normal diberikan semenjak tahap adaptasi selama tujuh hari dan terus diberikan pada kelompok K- hingga akhir perlakuan. Diet tinggi lemak diberikan terhitung setelah masa adaptasi hingga empat minggu pada kelompok $\mathrm{K}+, \mathrm{P} 1, \mathrm{P} 2$ dan $\mathrm{P} 3$, pemberian ini dilakukan sebagai usaha mimicking kemudian kelompok tersebut dibuat menjadi diabetes dengan menyuntikkan streptozotocin (STZ) dosis 40 $\mathrm{mg} / \mathrm{kg} \mathrm{BB}$ secara intraperitonial [12-14].

Perubahan kondisi menjadi diabetes diamati setelah penyuntikan dengan pengukuran gula darah acak ekor tikus selama 3 hari berturut-turut.
Keberhasilan efek STZ diukur dari peningkatan kadar gula darah menjadi $\geq 200 \mathrm{mg} / \mathrm{dl}$. Setelah dinyatakan diabetes, diet tinggi lemak dilanjutkan diberikan pada $\mathrm{K}+$ hingga akhir penelitian. Sedangkan kelompok P1, P2 dan P3 diberikan diet tinggi lemak yang sebagian komposisinya disubstitusi dengan dosis tepung susu sapi masing-masing kelompok. Pemberian ini dilanjutkan hingga akhir penelitian.

Hari ke-91 seluruh tikus di euthanasia oleh laboran ahli dari laboraturium menggunakan ether untuk menghindari adanya efek negatif pada organ tikus terutama pada organ pankreas pada penelitian ini, penggunaan eter hanya mengakibatkan efek secara fisik pada paru-paru $[15,16]$. Selanjutnya kadar NF-K $\beta$ pada pankreas diukur menggunakan Enzyme-linked Immunosorbent Assay (ELISA). Data yang diperoleh kemudian dianalisis dengan menggunakan SPSS 20 for Mac pada signifikansi 0,05 dan taraf kepercayaan $95 \%$. Seluruh metode dalam penelitian ini telah diperiksa dan disetujui oleh komisi etik Fakultas Kedokteran Universitas Brawijaya berdasarkan surat komisi etik: No. 566/EC/KEPK/12/2013.

\section{HASIL PENELITIAN}

Pada akhir penelitian jumlah sampel yang tersedia berbeda pada tiap kelompoknya karena ada drop out akibat tikus mati selama perlakuan. Data akhir jumlah akhir adalah sebagai berikut: kelompok $\mathrm{K}-=6$ ekor, $\mathrm{K}+=4$ ekor, $\mathrm{P} 1=6$ ekor, $\mathrm{P} 2=5$ ekor, dan kelompok P3 $=4$ ekor tikus. Seluruh data akhir diperoleh dengan menggunakan hasil seluruh sampel yang tersedia pada tiap kelompok di akhir penelitian dengan " $n$ " yang berbeda. Sedangkan data awal penelitian diperoleh dari seluruh kelompok dengan memiliki jumlah " $n$ ” yang sama.

\section{Hewan Coba}

Hasil analisis pada berat badan tikus diawal penelitian menunjukkan berat badan awal memenuhi kaidah normalitas, dibuktikan dengan nilai $\mathrm{p}>0,05$ $(0,631 ; 0,600 ; 0,165 ; 0,594)$. Sedangkan hasil uji homogenitas menunjukkan nilai $p>0.05 \quad(p=0.074)$ sehingga dinyatakan berat badan tikus adalah homogen. 
Tabel 1. Karakteristik Hewan Coba

\begin{tabular}{|c|c|c|c|c|c|}
\hline Karakteristik & $\mathbf{K}(-)$ & $\mathbf{K}(+)$ & P1 & $\mathbf{P 2}$ & $\mathbf{P 3}$ \\
\hline Jenis Tikus & \multicolumn{5}{|c|}{ Rattus norvegicusstrain Wistar } \\
\hline Usia & \multicolumn{5}{|c|}{$2-3$ bulan } \\
\hline Jenis Kelamin & \multicolumn{5}{|c|}{ Jantan } \\
\hline Warna Bulu & \multicolumn{5}{|c|}{ Putih, bersih, lebat } \\
\hline Keadaan Umum & \multicolumn{5}{|c|}{ Sehat, tingkah laku dan aktivitas normal } \\
\hline $\begin{array}{l}\text { Berat Badan Awal } \\
\text { (gram) } \\
(\text { mean } \pm \text { SD) }\end{array}$ & $\begin{array}{c}178,3 \pm \\
27,86\end{array}$ & 220 & $\begin{array}{c}216,6 \pm \\
24,2\end{array}$ & $\begin{array}{c}226 \pm \\
48,2\end{array}$ & $\begin{array}{c}250 \pm \\
54,7\end{array}$ \\
\hline
\end{tabular}

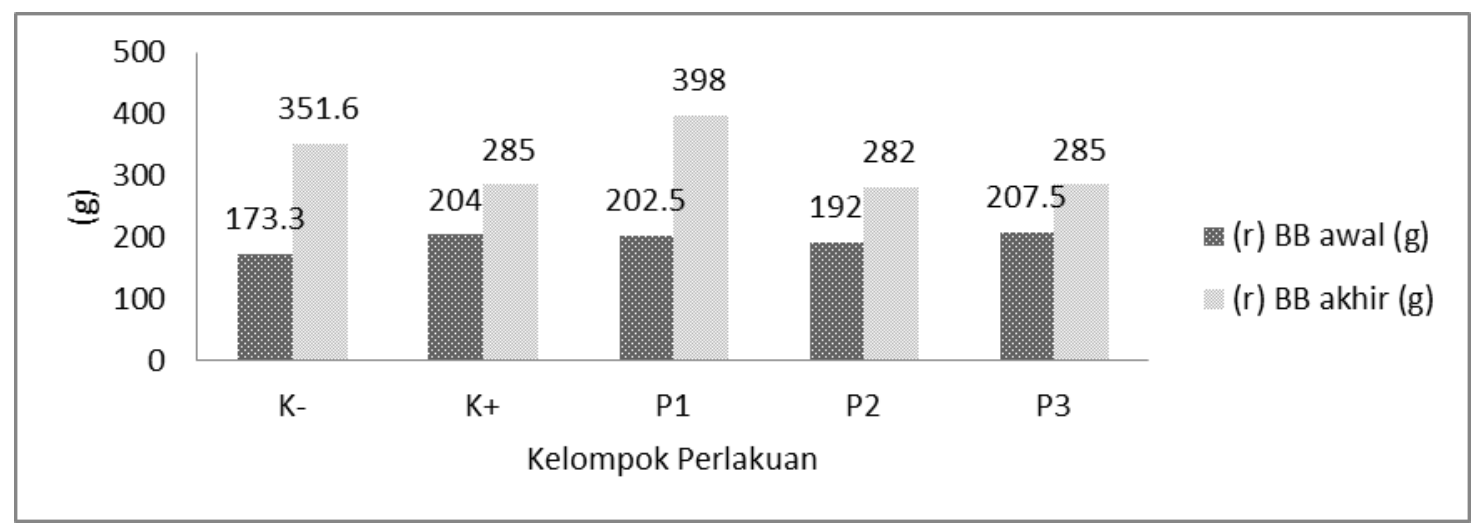

Gambar 1. Perubahan Rata-rata Berat Badan Tikus

Selama penelitian dilakukan, perubahan berat badan pada tikus terendah terjadi pada $\mathrm{P} 3( \pm 35 \mathrm{~g})$ dan tertinggi tercapai pada K- $( \pm 173,3 \mathrm{~g})$. Perubahan yang terjadi kemudian diukur normalitas dan homogenitasnya dan didapatkan hasil normal dan homogen ( $\mathrm{p}>0.05 ; \mathrm{p}=0.579)$. Berdasarkan hasil tersebut disimpulkan pemberian pakan isokalori berhasil memberikan pola pertumbuhan yang sama pada semua kelompok.

\section{Asupan Hewan Coba}

Asupan tikus diukur dari jumlah pakan yang diasup dibandingkan dengan kebutuhan hariannya. Rata-rata asupan pakan tikus selama penelitian berdasarkan uji normalitas dan homogenitas ( $p>0.05$; $\mathrm{p}=0.498$ ), menunjukkan asupan rata-rata seluruh kelompok adalah tidak berbeda. 


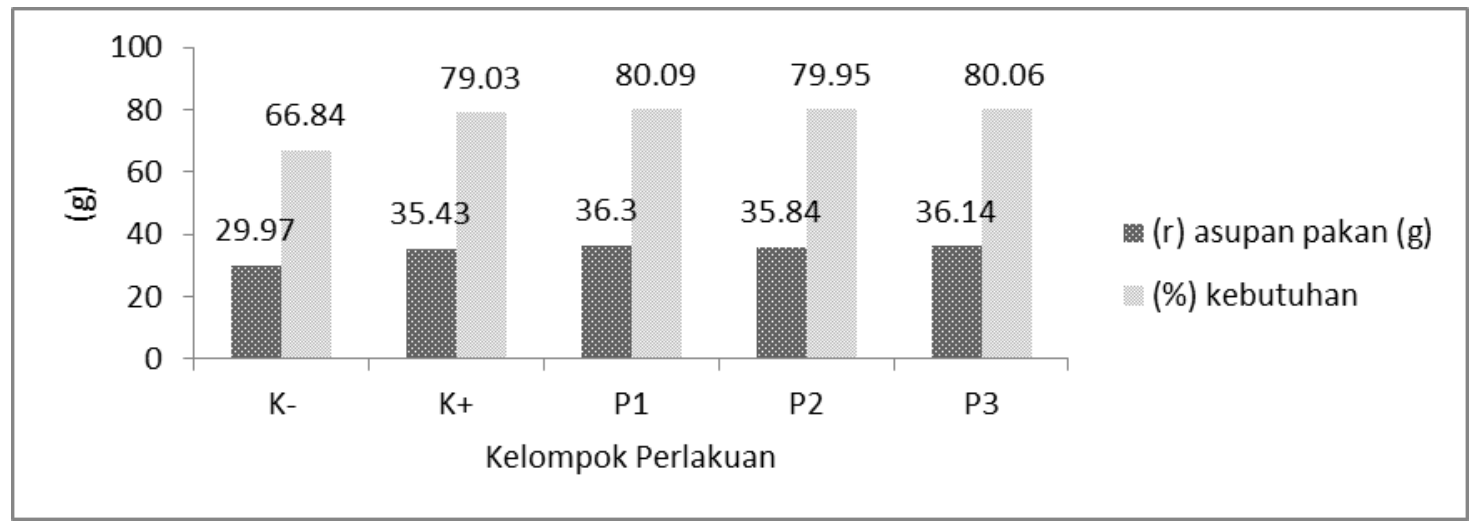

Gambar 2. Rata-rata Asupan Pakan Tikus

Asupan rata-rata tertinggi ditemukan pada P1 sebesar 36,3 g (80\% kebutuhan) dan terendah diketahui berada pada K- sebesar 29,9 g (66,8\% kebutuhan). Poliphagi merupakan salah satu faktor yang mempengaruhi asupan pada kelompok perlakuan.
Sedang untuk asupan total energi dibandingkan kebutuhan diperoleh data sebagai berikut, total asupan energi tertinggi berada pada P3 sebesar 112,3 Kal (76\% kebutuhan) dan terendah pada $\mathrm{K}$ - sebesar 86,1 Kal (64,1\% kebutuhan). Uji normalitas dan homogenitas menunjukkan tidak ada perbedaan asupan diantara kelompok ( $\mathrm{p}>0,05 ; \mathrm{p}=0,498)$.

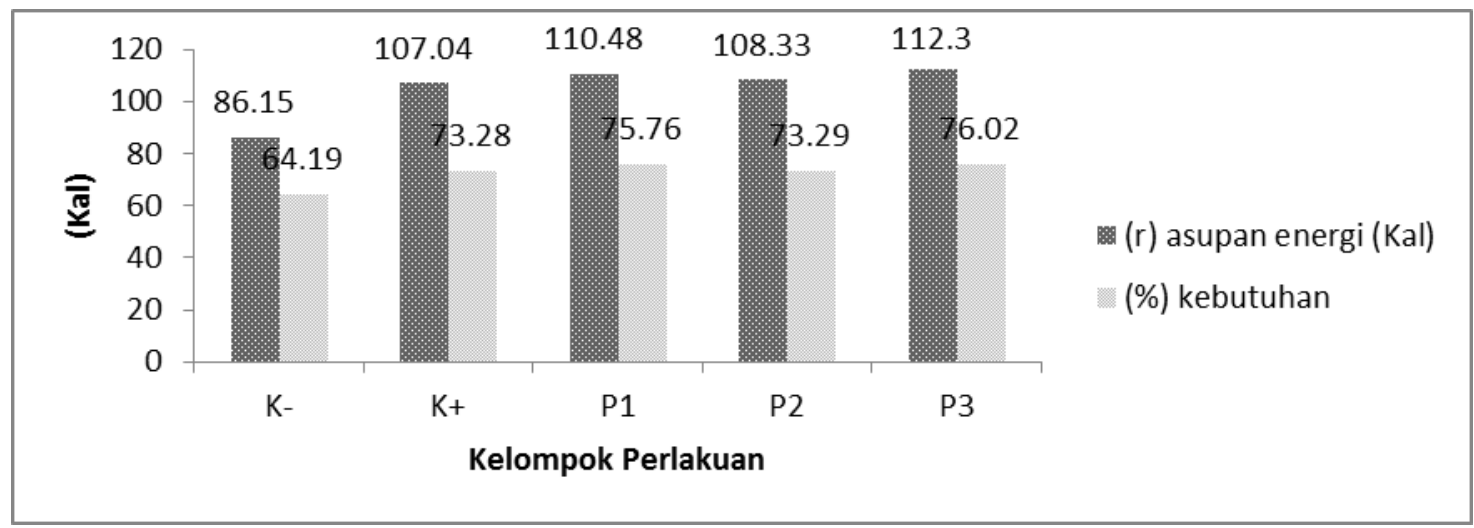

Gambar 3. Rata-rata Asupan Energi Tikus

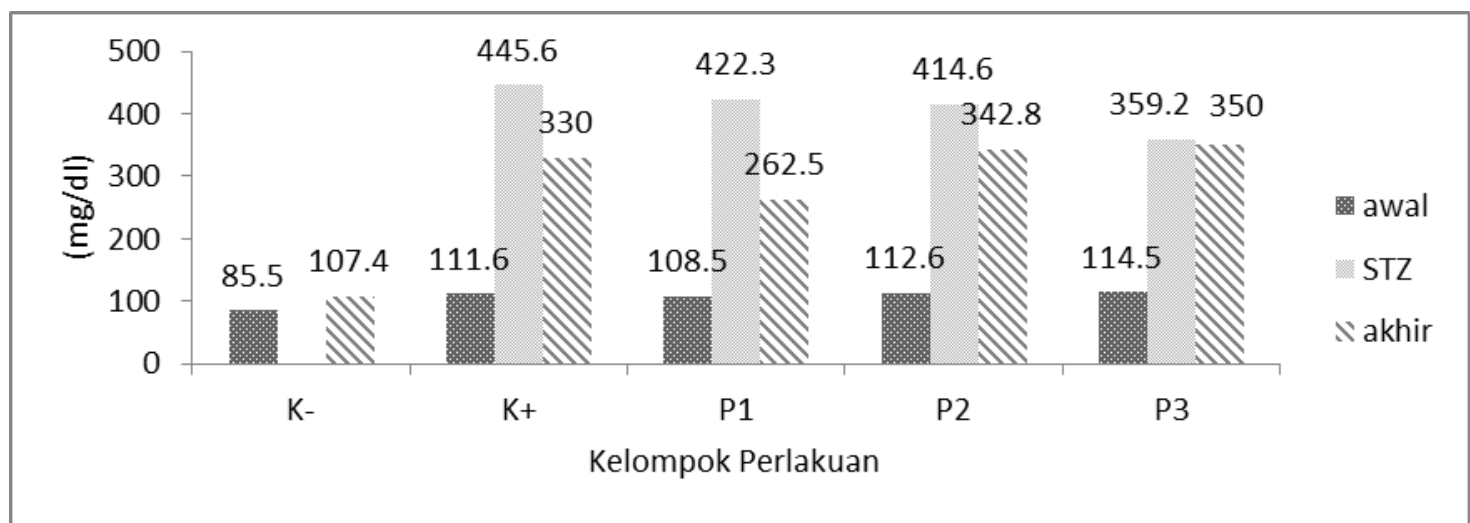

Gambar 4. Profile Gula Darah Tikus selama Percobaan 


\section{Kadar Gula Darah Hewan Coba}

Hasil pemantauan kadar glukosa darah selama penelitian menunjukkan setelah injeksi STZ gula darah kelompok $\mathrm{K}+, \mathrm{P} 1, \mathrm{P} 2$, dan $\mathrm{P} 3$ mengalami peningkatan $(>200 \mathrm{mg} / \mathrm{dl})$ dari nilai gula darah awal masing-masing kelompok dan mengindikasikan keadaan diabetes dibandingkan dengan kelompok K-.

Penurunan gula darah ditemukan pada kelompok P1, P2 dan P3, termasuk kelompok $\mathrm{K}+$ yang tidak memperoleh perlakuan. Hasil uji Shapiro Wilk untuk normalitas menunjukkan seluruh gula darah awal dan akhir pada kelompok tikus adalah normal $(\mathrm{p}>0,05)$.

Sedangkan untuk uji homogenitas menunjukkan untuk kadar gula darah awal hasil levene test menunjukkan data homogen $(p>0,05)$, dan menunjukkan kadar gula akhir diketahui tidak homogen $(\mathrm{p}<0,05)$.

Uji One way Anova kemudian dilakukan untuk mengetahui ada tidaknya perbedaan gula darah awal dan akhir. Hasil menunjukkan tidak ditemukan perbedaan gula darah awal dan akhir $(\mathrm{p}>0,05)$.
Perbedaan yang tidak signifikan dapat dimungkinkan karena adanya drop out pada beberapa kelompok, sehingga variasi yang terjadi menjadi tidak dapat diketahui. Penggunaan STZ memang memiliki kecenderungan mengarahkan pada Type 1 DM karena fungsinya yang mengiduksi kerusakan sel beta pancreas tetapi banyak digunakan untuk menyediakan model Type 2 saat ini melalui kombinasi pengarturan dosis dan diet tinggi lemak [17].

\section{Kadar NF-K $\beta$ Hewan Coba}

Kadar rata-rata NF-K $\beta$ diukur dari organ pankreas. Hasil menunjukkan kadar tertinggi ditemukan pada kelompok $\mathrm{K}+$ sebesar $839 \mathrm{ng} / \mathrm{ml}$. Sedangkan kadar terendah pada kelompok perlakuan tepung susu sapi adalah kelompok P3 dengan kadar rata-rata sebesar $442 \mathrm{ng} / \mathrm{ml}$.

Kadar terendah yang dicapai oleh kelompok perlakuan masih belum dapat sebanding dengan kadar pada kelompok $\mathrm{K}$ - yang memiliki rata-rata kadar sebesar $87,5 \mathrm{ng} / \mathrm{ml}$. Tetapi kadar ini memiliki nilai yang lebih rendah dibandingkan dengan kelompok $\mathrm{K}+$.

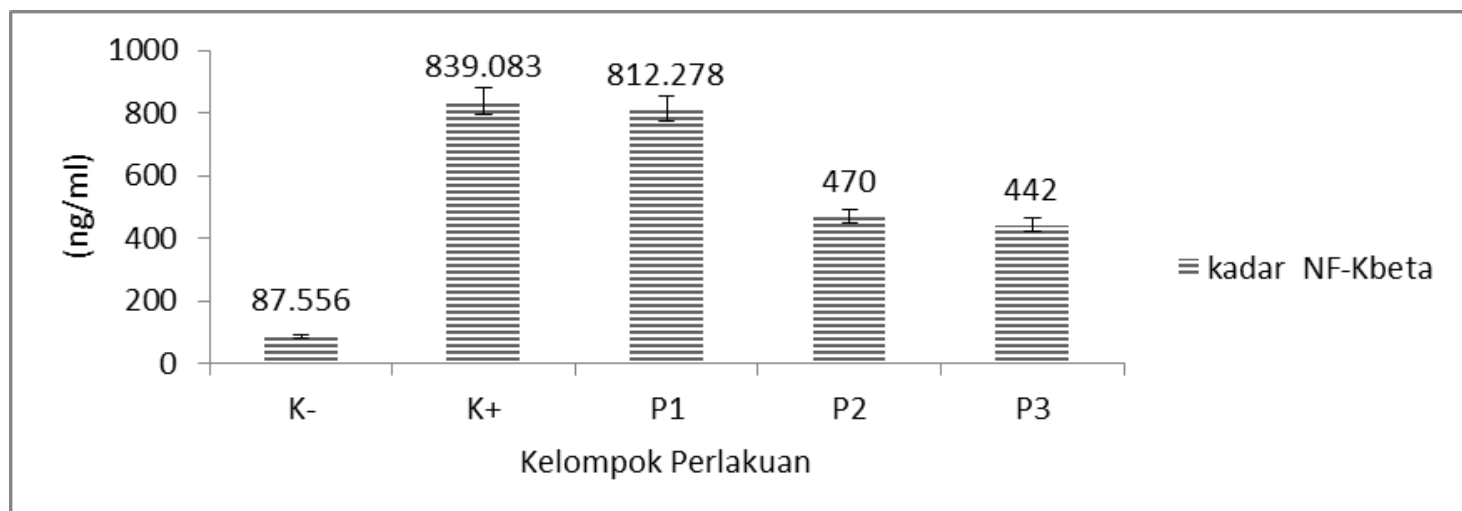

Gambar 5. Profile Kadar NF-K $\beta$ Tikus

Data tersebut kemudian diuji untuk mengetahui normalitas dan homogenitasnya. Hasil uji menunjukan data tidak normal dan tidak homogen $(\mathrm{p}<0,05)$. Untuk mengetahui apakah terdapat perbedaan maka data diuji dengan uji Kruskal-Wallis. Hasil uji menunjukkan terdapat perbedaan signifikan $(\mathrm{p}=0,03)$. Berdasarkan hasil tersebut, dapat disimpulkan bahwa terdapat perbedaan antara kelompok perlakuan.

Selanjutnya dilakukan uji lanjut terhadap data dengan uji Mann-Withney $U$ agar dapat diketahui kelompok mana yang memberikan perbedaan secara signifikan. Hasil yang diperoleh menunjukkan tidak ditemukan kelompok perlakuan yang memberikan perbedaan secara signifikan $(\mathrm{p}=1.000 ; 0.086 ; 0.248)$.

Penurunan kadar NF-K $\beta$ yang terjadi tidak cukup besar nilainya sehingga tidak dapat secara nyata kelompok mana yang berbeda diantara kelompok perlakukan dan perbedaan terhadap kelompok kontrol. 


\section{PEMBAHASAN \\ Hewan Coba}

Berat badan tikus pada awal penelitian dinyatakan normal dan homogen ( $>>0.05)$. Mengindikasikan bahwa pada awal penelitian semua tikus dalam keadaan yang sebanding dan sesuai dengan kriteria yang ditetapkan.

Selama penelitian tikus diberikan pakan isokaloric yang mengandung total kalori seragam tetapi dengan komposisi zat gizi yang berbeda. Perubahan berat badan yang terjadi kembali diuji normalitas dan homogenitasnya.

Tujuan pengujian ini adalah untuk mengetahui apakah perubahan yang terjadi diperoleh dari efek pakan yang diberikan. Hasil uji normalitas dan homogenitas $(p>0,05)$ menunjukkan pemberian pakan isokalorik dapat memastikan perubahan yang dialami adalah hasil dari perlakuan yang diberikan, dan tidak karena perbedaan asupan.

Pada akhir penelitian tidak ditemukan penurun berat badan yang sering menyertai keadaan diabetes. Penurunan berat badan disebabkan pada kondisi diabetes tubuh tidak mampu menggunakan glukosa sebagai sumber energi akibat kekurangan insulin. Sehingga terjadi pemecahan simpanan lemak sebagai kompensasi alternatif substrat untuk menghasilkan energi [18].

Pemberian diet tinggi lemak pada kelompok $\mathrm{K}+, \mathrm{P} 1, \mathrm{P} 2$ dan $\mathrm{P} 3$ diduga merupakan penyebab mengapa berat badan tidak turun. Faktor kedua adalah penurunan berat badan pada keadaan diabetes membutuhkan waktu sampai dengan masa kompensasi kekurangan energi belum tercapai pada rentang waktu penelitian ini. Bila tahap ini akan tercapai maka kekurangan energi ini menyebabkan terjadinya proses glukoneogenesis masive di hepar, sehingga menyebabkan hilangnya masa otot [19].

\section{Asupan Hewan Coba}

Hasil data menunjukkan bahwa terjadi peningkatan asupan makan dan total energi pada setiap kelompok. Peningkatan yang terjadi disebabkan karena kebutuhan setiap tikus mengikuti pertambahan usianya. Peningkatan asupan makan dan energi diantara kelompok normal dan homogen, tidak ditemukan perbedaaan.

Hal yang perlu menjadi perhatian adalah adanya selisih peningkatan asupan makan dan energi antara $\mathrm{K}$ - dibandingkan $\mathrm{K}+, \mathrm{P} 1, \mathrm{P} 2$ dan P3. Pada kelompok diabetes peningkatan asupan terjadi lebih tinggi dari pada kelompok non diabetes berdasarkan nilai.
Poliphagia adalah keadaan yang mendorong peningkatan asupan pada keadaan diabetes. Intake yang tinggi didorong oleh kegagalan penggunaan gula darah oleh sel walaupun kadarnya tinggi pada sirkulasi. Rasa lapar yang berlebihan adalah penanda kondisi ini [20]. Hasil ini lebih jauh dapat dihubungkan dengan kondisi penambahan berat badan yang lebih tinggi ditemukan pada kelompok perlakuan.

\section{Kadar Gula Darah Hewan Coba}

Peningkatan kadar gula darah yang terjadi sebagai indikasi adanya Type 2 diperoleh melalui kombinasi pemberian diet tinggi lemak dan injeksi STZ. Pemberiaan ini dimaksudkan agar tercapai keadaan hiperglikemia dan hiperlipidemia, dimana pada fase ini resistensi insulin akan terjadi sebagaimana keadaan awal penderita Type 2 .

Setelah empat minggu pemberian diet tinggi lemak dilanjutkan dengan injeksi STZ agar sel pankreas terpicu untuk rusak dan kondisi diabetes tercapai. Prosedur ini juga ditujukkan untuk mencegah kecenderungan kesalahan metabolik type 1 terjadi pada model [17, 21-23]. Selanjutnya perubahan gula darah akan diawali dengan peningkatan gula darah setelah dilakukan injeksi STZ. Peningkatan ini dapat menjadi indikasi keadaan diabetes bila gula darah terperiksa $\geq 200$ $\mathrm{mg} / \mathrm{dl}[19]$.

Setelah dinyatakan diabetes kemudian dilakukan pemberian tepung susu sapi pada kelompok perlakuan. Pada akhir penelitian gula darah kelompok perlakuan P1, P2 dan P3 yang memperoleh tepung susu sapi mengalami penurunan kadar gula darah dibandingkan gula darah awal yang tidak signifikan. Penurunan gula darah ini adalah bukti bahwa pemberian tepung susu sapi sapi dapat menurunkan gula darah pada keadaan diabetes melitus, melalui mekanisme vitamin D dan kalsium [24-26].

Hal ini dimungkinkan pula karena selain kemampuan vitamin D dan kalsium yang dimiliki tepung susu sapi, didalam susu sapi juga terdapat kandungan Branch Chain Amino Acids (BCAA) dan whey protein yang dapat menurunkan kadar gula darah melalui mekanisme peningkatan insulin postprandial dan memperbaiki kontrol insulin serta keseimbangan glukosa [27].

Tetapi penurunan darah yang terjadi tidak signifikan, hal yang perlu diketahui adalah kondisi yang berbeda ditemukan pada penelitian ini dimana semakin besar dosis tepung susu semakin kecil 
penurunan gula darah yang terjadi bila dibandingkan dengan dosis kecil.

Perbedaan yang terjadi belum dapat dijelaskan melalui penelitian ini, tetapi peneliti menduga dapat berhubungan karena perbedaan respon individu dan berkurangnya jumlah sampel pada akhir penelitian. Lebih lanjut tidak signifikan-nya penurunan gula darah pada kelompok perlakukan tentunya akan berhubungan dengan kadar NF-K $\beta$ yang diperoleh pada akhir penelitian.

\section{Kadar NF-K $\beta$ Hewan Coba}

Kadar NF-K $\beta$ pada kelompok perlakuan menurun jumlahnya sebanding dengan peningkatan dosis tepung susu sapi yang diberikan. Hal ini menunjukkan bahwa peran vitamin $\mathrm{D}$ terhadap penurunan NF-K $\beta$ terbukti.

Vitamin $\mathrm{D}$ melalui mekanisme pengikatan kalsium sitosolik yang dilakukan oleh Calbidin pada sel beta pankreas akan menghasilkan efek pada penghambatan NF-K $\beta$ maka resistensi insulin menurun [28]. Calbidin juga melakukan proteksi terhadap proses apoptosis pada sel pankreas jika kalsium sitosolik masih dalam keadaan tinggi jumlahnya sehingga kerusakan sel tidak berlanjut [3]. Selanjutnya kemampuan vitamin D yang dimungkinkan dapat mempengaruhi proses penurunan kadar NF-K $\beta$ lainnya adalah melalui jalur vitamin $\mathrm{D}$ receptor (VDR). Melalui VDR, vitamin $\mathrm{D}$ akan mempengaruhi Inhibitor of NF-K $\beta$ (IKKB) sehingga terjadi hambatan aktivasi NF-K $\beta$ [29].

Pada tahap berikutnya interaksi antara VDR dan IKKB akan menghambat pembentukan IKB Kinase (IKK) yang akan menghasilkan feedback penurunan fosforilasi IKKB [29]. Penurunan fosforilasi akan membatalkan IKK dan kembali akan menurukan fosforilasi [30]. Secara berulang proses ini dapat mencegah kerusakan pada pancreas lebih lanjut dan secara tidak langsung akan ikut menjadi penyebab penurunan gula darah.

Pada penelitian ini penggunaan STZ pada model hewan coba dapat mengakibatkan kerusakan pada sel pancreas, menimbang dari ulasan tersebut maka penelitian ini melakukan pemeriksaan NF-K $\beta$ pada site dimana reaksi inflamasi terjadi, sekaligus ditujukkan untuk mengetahui seberapa besar kemampuan perlakuan yang diberikan dapat menjaga kondisi sel pancreas yang tersisa. Tetapi penelitian ini tidak dapat memastikan apakah reaksi yang dimunculkan oleh STZ dapat sepenuhnya ditangani oleh pemberian perlakuan. Sehingga sangat mungkin mekanisme ini dapat dianalisis lebih lanjut.

Kemampuan vitamin D terhadap kontrol gula darah adalah mekanisme akhir yang terlibat dalam penghambatan kompliklasi vaskuler dan penurunan gula darah, HOMA-IR and A1c [31]. Mekanisme ini dapat dihubungkan dengan adanya penurun profil gula darah pada kelompok perlakuan sebagaimana telah dibahas sebelumnya, walaupun hasil penurunan yang diharapkan belum tercapai.

Berdasarkan hal-hal tersebut dapat diketahui bahwa kemampuan tepung susu sapi dalam memperbaiki kadar NF-K $\beta$ dan bagaimana kadar NF-K $\beta$ dapat mempengaruhi penurunan gula darah pada kelompok perlakuan tidak dapat dibuktikan pada penelitian ini. Keadaan yang menunjukkan tidak signifikannya hasil tidak dapat dikatakan sebagai kegagalan, tetapi terlebih merupakan mekanisme yang belum dapat terjelaskan pada penelitian ini.

\section{KESIMPULAN}

Tepung susu sapi dapat menurunkan NF-K $\beta$ pada tikus model type 2 Diabetes Mellitus tetapi penurunan yang terjadi tidak signifikan bila dibandingkan dengan kontrol diabetes. Dosis tepung susu sapi yang dapat menurunkan kadar NF-K $\beta$ efektif adalah $6,75 \%$ total pakan dengan efek penurunan NF-K $\beta$ sebesar 442 ng/ml. Kadar NF-K $\beta$ ini adalah kadar terendah yang dapat dicapai mendekati kadar normal pada kelompok kontrol non-diabetes.

\section{SARAN}

Perlu penelitian lebih lanjut untuk mengetahui mekanisme yang ikut terlibat dalam menentukan bagaimana kandungan vitamin $\mathrm{D}$ dan kalsium pada tepung susu sapi dapat optimal memberikan efek perbaikan kadar NF-K $\beta$ dan secara tidak langsung ikut mengontrol hiperglikemia.

\section{DAFTAR RUJUKAN}

1. Wan NI, Syed, A., Aniza, I. Cost of Type 2 Diabetes Melitus in Selected Developing Countries. Malaysian Journal of Public Health Medicine. 2010;10 (2):68-71.

2. Wild S, Roglic, G., Green, A., Sicree, R., King, H. Global Prevalence of Diabetes: Estimates for the Year 2000 and Projections for 2030. Diabetes Care. 2004;27:1047-453. 
3. Anastassios GP, Joseph, L. F., Bess, DH. Review: The Role of Vitamin D and Calcium in Type 2 Diabetes. A Systematic Review and Meta-Analysis. The Journal of Clinical Endocrinology and Metabolism. 2007;92(6):2017-29.

4. Putra HB, Ratnawati,R.,Yudani, T. Efek Polifenol Buah Tin (Ficus carica L.)terhadap Kadar Nuclear Factor Kappa B (NFKB) pada Aorta Tikus (rattus norvegicus L.) Galur Wistar Jantan yang Diberi Diet Atherogenik. Research Report. 2012.

5. Patel S, Dev, S. Role NFKB in the Pathogenesis of Diabetes and its Associated Complications. Pharmacological Reports. 2009;61:595-603.

6. Alfonso B. Vitamin D in Diabetes Melitus A New Field of Knowledge Poised for Development. Diabetes Metab Res Rev. 2009;25:417-9.

7. Tracy SM, Mazen J. H. The Role of Vitamin D Deficiency in The Pathogenesis of Type 2 DiabetesMellitus. European Journal of Clinical Nutrition and Metabolism. 2010;5:155-65.

8. Slette J, Meylinah, S. Indonesia Dairy and Products Annual Report 2012. 2012.

9. The World Dairy Situation. [press release]. Belgium: International Dairy Federation 2010 2010.

10. Göttingen. Routes of Administration Procedures. Germany: University of Göttingen; 2000. p. 463-82.

11. Eryna R. Analisis Kadar High Density Lipoprotein (HDL) Serum pada Tikus (Rattus norvegicus starin wistar) Jantan yang Diberi Diet Aterogenik [Skripsi]. Malang: Universitas Brawijaya; 2015.

12. Gajdosík A, Gajdosíková, A., Stefek, M., Navarová, J., Hozová ,R. Streptozotocininduced experimental diabetes in male Wistar rats. Gen Physiol Biophys. 1999;18 Spec 54-62.

13. Zhiyong W, Helga, G. GLUT2 in Pancreatic Islets: Crucial Target Molecule in Diabetes Induced With Multiple Low Doses of Streptozotocin in Mice

. Diabetes. 1998;47:1-7.

14. Fructose-fed streptozotocin-injected rat: an alternative model for type 2 diabetes [press release]. Durban, South Africa: University of KwaZulu-Natal (Westville Campus)2012.

15. American Veterinary Medical Association. AVMA Guidelines for the Euthanasia of
Animals. Schaumburg, IL 60173: American Veterinary Medical Association; 2013. p. 1-102.

16. Robert WJMS. Policy 4 Rodent Euthanasia. New Jersey: University of Medicine and Dentistry of New Jersey; 2013. p. 1-14.

17. Remya R, Veluchamy, A. B., Shyam, S. C., Tien, Y. W.,Timothy, S. K. Update on Animal Models of Diabetic Retinopathy: From Molecular Approaches to Mice and Higher Mammals. Disease Model and Mechanism. 2012;5(4):444-56.

18. Suriani N. Gangguan Metabolisme Karbohidrat pada Diabetes Melitus [Thesis]. Malang: Brawijaya; 2012.

19. Amirshahrokhi A, Dehpour, J., Hadjati, M., Sotoudeh, M., Ghazi-Khansari. Methadone ameliorates multiple-low-dose streptozotocininduced type. Toxicology and Applied Pharmacology 2008;232:120-4.

20. Sabine K, Michael, R. An Update on The Pathogenesis of Type 2 Diabetes Mellitus. Hamdan Medical Journal 2012. 2012;5:99-122.

21. Ming Z, Xiao-Yan, Lv., Jing, L., Zhi-Gang, X., $\mathrm{Li}, \mathrm{C}$. The Characterization of High-Fat Diet and Multiple Low-Dose Streptozotocin Induced Type 2 Diabetes Rat Model. Experimental Diabetes Research. 2008;2008:1-9.

22. Agung EN. Hewan Percobaan Diabetes Mellitus: Patologi dan Mekanisme Aksi Diabetogenik. Biodiversitas. 2006;7(4):378-38.

23. Srinivasan K, Ramarao, P. Animal Models in Type 2 Diabetes Research: An Overview. Indian Journal Medical Research. 2007;125:451-72.

24. Dengfeng G, Ning, N., Congxia, W., Yuhuan, W., Qing, L., Zhe, M., Yang, L., Qiang, L. Dairy Products Consumption and Risk of Type 2 Diabetes: Systematic Review and DoseResponse Meta-Analysis. PLOS ONE. 2013;8(9):1-15.

25. Candido S. Dairy Products Consumption Versus Type 2 Diabetes Prevention And Treatment: A Review of Recent Findings From Human Studies. Nutr Hosp. 2013;28(5):1384-95.

26. Martin C. The Role of Vitamins in The Prevention and Treatment of Type 2 Diabetes and Its Complication. Journal of Diabetes Nursing. 2013;17(10):376-83.

27. Dugan C, Maria, LF. Effect of Dairy on Metabolic Syndrome Parameters: A Review. Yale Journal of Biology and Medicine. 2014;87:135-47. 
28. Pilz S, Kienreich, K., Rutters, F., de Jongh, R., van Ballegooijen, AJ., Grübler, M., Tomaschitz, A., Dekker, JM. Role of Vitamin D in the Development of Insulin resistance and Type 2 Diabetes. Curr Diab Rep. 2012;13(2):261-70.

29. Chen Y, Zhang, J., Ge, Xin., Du, D., Li, YC. Vitamin D Receptor Inhibits NFKB Activation by Interacting with IKK B Protein. J Biol Chem. 2013;288(27):19450-8.

30. Santangelo C. Polyphenols, Intracellular Signling and Inflamation. Ann 1st Super Santa. 2007;43:394-405.

31. Bahareh N, Tirang, R.N., Maryamosadat, F., Hamid, AM., Anahita, H., Ali, K., Nastaran, S., A'azam, G., Soudabeh, H., Nima, T., Shabnam, S., Malihe, Z. Daily Consumption of Vitamin D or Vitamin D + Calcium Fortified Yogurt Drink Improved Glycemic Control in Patient with Type 2 Diabetes : A Randomized Clinical Trial. American Journal of Clinical Nutrition. 2011;93:764-71. 